\title{
Role of intragastric and intraoesophageal alkalinisation in the genesis of complications in Barrett's columnar lined lower oesophagus
}

\author{
S E A Attwood, C S Ball, A P Barlow, L Jenkinson, T L Norris, A Watson
}

The Department of Surgery, Royal Lancaster Infirmary, Lancaster SE A Attwood

CS Ball

A P Barlow

L Jenkinson

T L Norris

A Watson

Correspondence to:

$S$ E A Attwood FRCSI, The Mater Hospital, Eccles St, Dublin 7, Eire.

Accepted for publication 8 June 1992

\begin{abstract}
Patients with Barrett's columnar lined lower oesophagus have severe acid gastrooesophageal reflux and may develop complications, including ulceration, stricture, and carcinoma. The aim of this study was to establish if a relationship exists between the pH profile in the oesophagus and stomach and the development of complications in patients with Barrett's columnar lined lower oesophagus. Twenty four hour ambulatory oesophageal pH monitoring was performed in 26 patients with Barrett's columnar lined lower oesophagus and combined with 24 hour ambulatory gastric pH monitoring in 16. Ten of the 26 with Barrett's columnar lined lower oesophagus had complications including stricture (eight), deep ulceration (one), and carcinoma (one). Oesophageal acid exposure (\% time $<\mathrm{pH} 4$ ) was similar in patients with or without complications $(19.2 \%$ v $19.3 \%$ p $>0.05)$. Oesophageal alkaline exposure (\% time $>$ pH 7) was greater in patients with complications $(24.2 \% v 8.4 \% p>0.05)$. Of the 16 patients who underwent gastric $\mathrm{pH}$ monitoring there was a clear relationship between gastric and oesophageal alkalinisation in 13. These results support the hypothesis that complications in Barrett's columnar lined lower oesophagus develop in association with increased exposure of the oesophagus to an alkaline environment which appears to be secondary to duodenogastric reflux. The routine use of 24 hour ambulatory gastric pH monitoring in conjunction with oesophageal pH monitoring can help identify those patients at risk.
\end{abstract}

(Gut 1993; 34: 11-15)

represent the worst end of the reflux spectrum with the most severe forms of lower oesophageal sphincter and pump failure and consequently greater degrees of acid exposure. ${ }^{7}$ It is unclear, however, why the columnarisation is prone to complications in some patients while remaining quiescent in others.

Bremner has proposed that the columnar lining in Barrett's oesophagus, being gastric in character, is acid resistant, but not bile resistant. ${ }^{58}$ DuPlessis ${ }^{9}$ and Lawson ${ }^{10}$ have both shown damage to gastric columnar epithelium by exposure to duodenal contents. Van der Veen et al have shown that previous gastric surgery represents an increased risk factor for the development of adenocarcinoma in Barrett's columnar lined lower oesophagus ${ }^{11}$ and Gillen et al have demonstrated increased bile acid concentrations in the stomach of patients who develop complications. ${ }^{12}$ Increased oesophageal alkaline exposure has been previously demonstrated in patients with Barrett's columnar lined lower oesophagus and it has been suggested that this might be secondary to increased duodenogastric reflux using discriminant analysis in a small number of patients. $^{7}$

The aim of this study was, first, to measure the $\mathrm{pH}$ profile in the lower oesophagus of patients with Barrett's oesophagus and by simultaneous ambulatory oesophageal and gastric $\mathrm{pH}$ monitoring, to correlate any alterations with changes in gastric $\mathrm{pH}$. The second aim was to relate the effects of acid and alkaline exposure to the development of complications in Barrett's oesophagus.

\section{Methods}

\section{PATIENTS}

Since the original description of a columnarised lower esophagus by Barrett in $1950^{1}$ and Allison and Johnson in $1953^{2}$ it has been recognised that this abnormal lining has a marked propensity to develop serious complications. These include stricture, ulceration, haemorrhage, perforation, and malignant degeneration. ${ }^{3-6}$ Such complications occur in approximately $50 \%$ of patients with Barrett's columnar lined lower oesophagus. ${ }^{+5}$ It is well recognised that patients with Barrett's columnar lined lower oesophagus
Patients were entered into the study after their first upper gastro-intestinal endoscopy showed Barrett's oesophagus. Oesophageal manometry and ambulatory gastric and oesophageal $\mathrm{pH}$ monitoring were performed within seven to 14 days of the first endoscopy. The results of $\mathrm{pH}$ monitoring (presence of abnormal acid and alkaline exposure in the oesophagus and stomach) and manometric findings (presence of defective lower oesophageal sphincter and defective oesophageal peristaltic pressure) were compared 
TABLE I Characteristics of patients with Barrett's columnar lined lower oesophagus comparing simple Barrett's with the complications of ulceration, stricture or malignant change

\begin{tabular}{lcc}
\hline & $\begin{array}{l}\text { Simple } \\
n=16\end{array}$ & $\begin{array}{l}\text { Complicated } \\
n=10\end{array}$ \\
\hline $\begin{array}{l}\text { Male:female ratio } \\
\begin{array}{l}\text { Age } \\
\text { Extent of Barrett's columnar } \\
\text { epithelium }\end{array}(\mathrm{cm})\end{array}$ & $\begin{array}{c}8: 8 \\
\text { (1) }\end{array}$ & $6: 4$ \\
\hline
\end{tabular}

^Values are means (standard deviation).

in patients with and without complicated Barrett's oesophagus (ulcer, stricture, or carcinoma).

Twenty six patients with Barrett's columnar lined lower oesophagus were diagnosed by endoscopic documentation of the squamocolumnar junction being circumferentially more than $3 \mathrm{~cm}$ above the endoscopically determined anatomical oesophagogastric junction. The demonstration of glandular epithelium (fundic, junctional, or intestinal metaplastic) in biopsy specimens from the lower oesophagus confirmed the diagnosis in all cases. Patients with previous oesophageal or gastric surgery were excluded from the study. The presence of complications was defined by the endoscopic demonstration of ulceration within the columnar lined segment (one), oesophageal adenocarcinoma (one), or oesophageal stricture (eight), the latter defined by a narrowing which prevented the smooth passage of a standard $(11 \mathrm{~mm})$ endoscope. The age and sex distribution of patients with and without complications in their Barrett's oesophagus is shown in Table $\mathrm{I}$.

NORMAL VALUES

The range of normal values for the oesophageal $\mathrm{pH}$ environment has been derived from previous study of 30 asymptomatic control subjects in this laboratory. ${ }^{13}$ Similarly the range of normal values

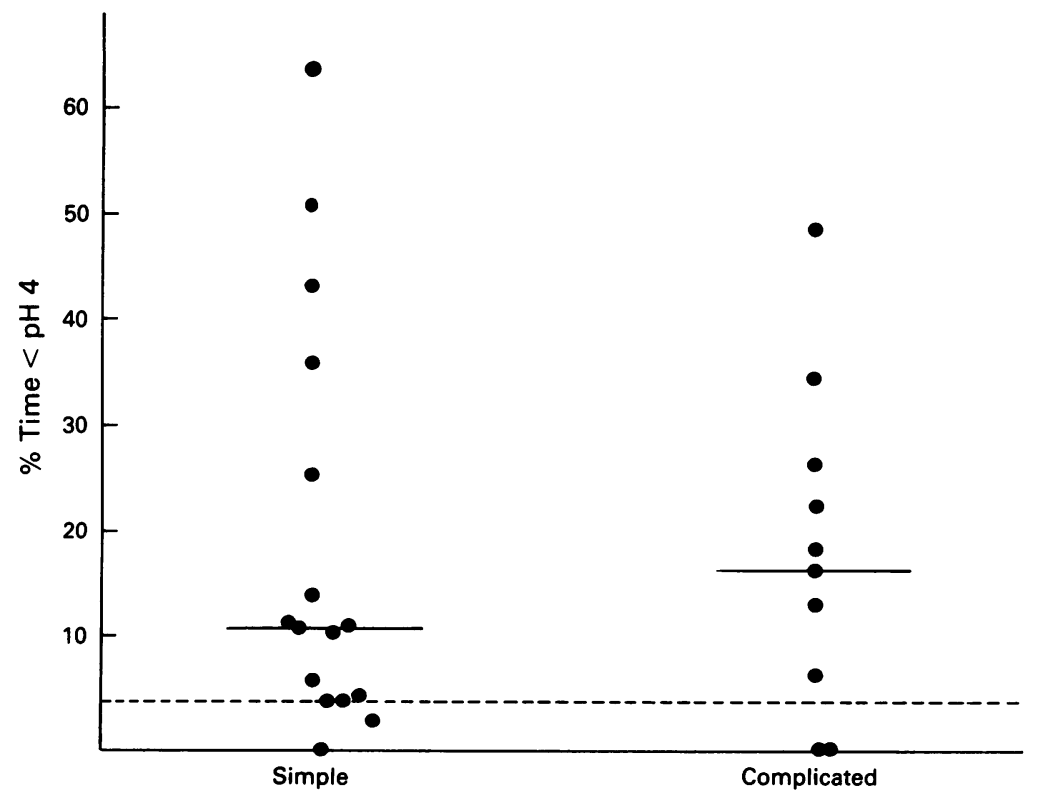

Figure 1: Median peristaltic amplitude during wet swallows at each level of the oesophageal body illustrating the poor motility in patients with Barrett's oesophagus with and without complications, compared with the normal range (10th and 90 th percentiles outlined by boxes). for gastric $\mathrm{pH}$ monitoring has been derived from studies in 10 asymptomatic control subjects who had simultaneous ambulatory oesophageal and gastric $\mathrm{pH}$ monitoring. ${ }^{1+}$

\section{MANOMETRY}

Oesophageal manometry was performed using a catheter containing five solid state transducers located at $5 \mathrm{~cm}$ intervals along its length and oriented radially around the circumference of the catheter (Gaeltec Ltd, UK). This was attached to a multichannel pen recorder (Lectromed, UK). All procedures were performed in fasted patients. With the patient in the supine position the manometry catheter was passed transnasally into the stomach. The lower oesophageal sphincter was assessed by the station pull through method of Winans and Harris, ${ }^{15}$ measuring the lower border of the high pressure zone (defined by a rise in the end-expiratory pressure of $2 \mathrm{~mm} \mathrm{Hg}$ or more above gastric baseline) and the upper border (return of the end expiratory pressure to within $2 \mathrm{~mm} \mathrm{Hg}$ of the thoracic baseline) as well as the respiratory inversion point and the end expiratory pressure at each station.

Oesophageal body peristalsis was measured by placing the catheter in the oesophageal body at representative levels and asking the patient to swallow a $5 \mathrm{ml}$ water bolus, or dry swallow alternately for 10 swallows. Oesophageal peristaltic amplitude was measued at each of six representative levels along the length of the oesophagus. The mean amplitude at each level was then plotted on charts where the 90th and 10th percentiles of pressure at these levels in our previously defined normal volunteers were represented by horizontal boxes ${ }^{16}$ (Fig 1). Impaired peristalsis was defined as a mean pressure outside the lower limit of normal for that level. These lower limits of normality correspond well with the pressures of ineffective peristalsis as defined by Kahrilas and Dodds. ${ }^{17}$

\section{pH MONITORING}

All 26 patients underwent 24 hour ambulatory oesophageal $\mathrm{pH}$ monitoring. Sixteen patients underwent simultaneous ambulatory oesophageal and gastric pH monitoring. All strictures were dilated at the time of diagnosis (and before $\mathrm{pH}$ monitoring when found at presentation). Patients were asked to withhold acid reducing medication for 48 hours before the study. $\mathrm{H}_{2}$ receptor blockers and Gaviscon were the only acid suppressing agents taken by this group of patients and no patients were taking proton pump blockers.

Two antimony $\mathrm{pH}$ probes (Monocrystant Mod 0011, Synectics Medical, Sweden) were calibrated at $\mathrm{Ph} 1$ and 7 at $35^{\circ} \mathrm{C}$ before the study and then passed transnasally so that the upper probe lay $5 \mathrm{~cm}$ proximal to the upper border of the manometrically determined lower oesophageal sphincter and the lower probe $10 \mathrm{~cm}$ distal to its lower border. A silver-silver chloride reference electrode was attached to the skin on the chest wall. The probes were connected to a portable recorder (Digitrapper - Synectics 


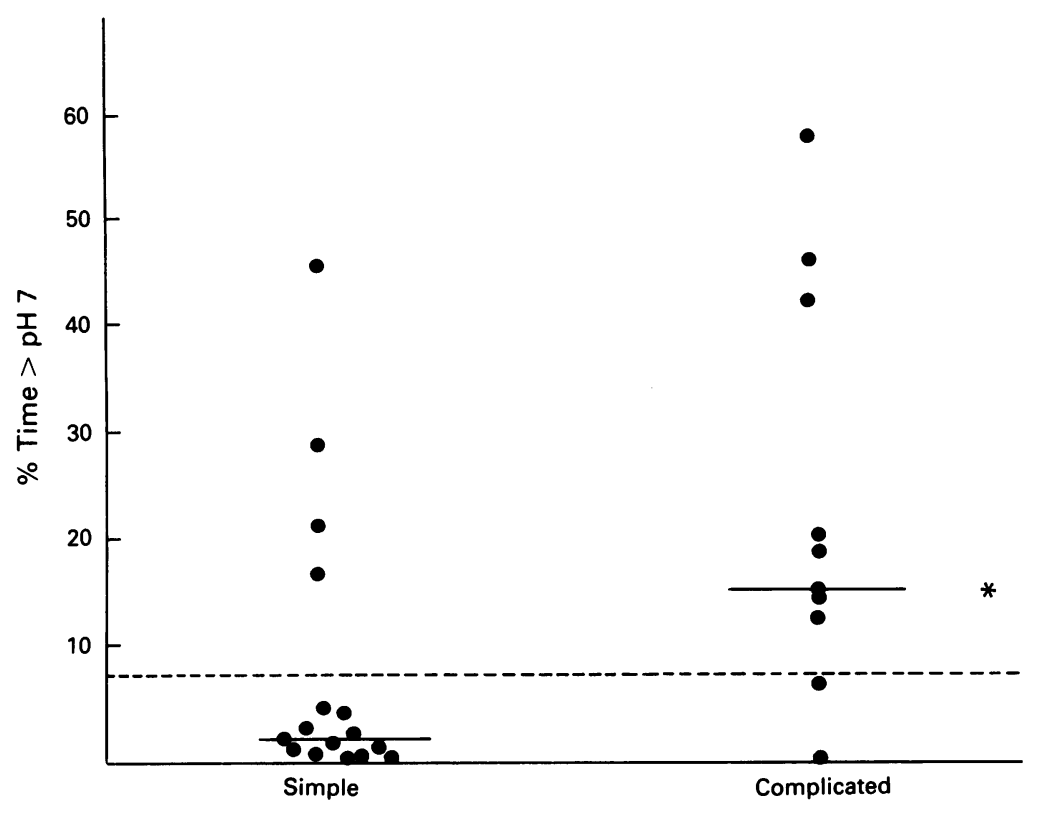

Figure 2: Percentage time that the lower oesophagus was exposed to acid $(\mathrm{pH}<4)$ in patients with simple or complicated Barrett's oesophagus. NS =no significant difference, $p>0 \cdot 05$ Wilcoxon's rank sum test. .... = upper limit of normal, $-=$ median acid exposure (median $=10 \cdot 8 \%$, interquartile range 5-18\% for simple Barrett's versus 6.6-26\% for complicated Barrett's oesophagus).
Medical, Sweden) capable of holding data from two channels over a period of 24 hours. Sampling frequency was once every four seconds. During the study the patients were asked to consume a standard diet ${ }^{18}$ and to record their meal and sleep periods and any symptoms in a diary. The data were off loaded to a computer (Amstrad PC1640, IBM-compatible) and processed using the Esophagram software (Gastrosoft Ltd, USA). For the purposes of this study the percentage of the time that the intraoesophageal $\mathrm{pH}$ was below 4 and above 7 was calculated, as was the percentage of time that the intragastric $\mathrm{pH}$ was above 4 as well as documentation of individual alkalinisation episodes. The normal upper limits of oesophageal acid and alkaline exposure as defined by the 90 percentile in our normal

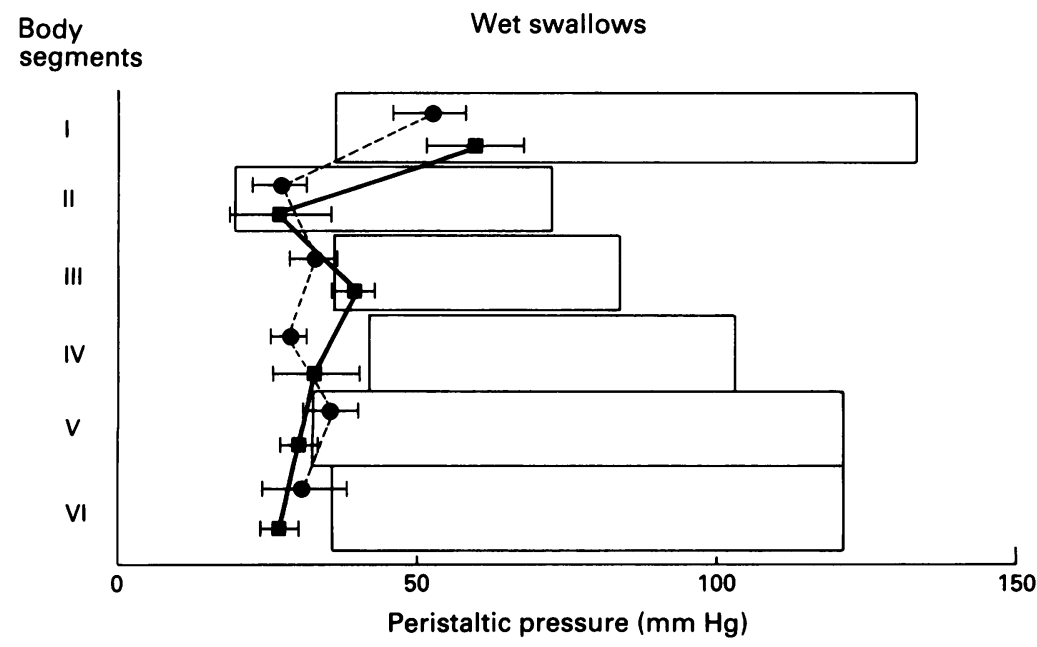

Figure 3: Percentage time that the lower oesophagus was exposed to alkali $(p H>7)$ in patients with simple or complicated Barrett's oesophagus. ${ }^{\star}=$ significant difference, $p<0.05$,

Wilcoxon's rank-sum test. .... =upper limit of normal, $-=$ median alkaline exposure (median = $2 \cdot 1 \%$, interquartile range $0.8 \%$, for simple Barrett's versus $15 \%$ interquartile range $11-25 \%$ for complicated Barrett's oesophagus). volunteers was $5 \cdot 1 \%$ and $8 \cdot 4 \%$ respectively. The corresponding values for percentage of the time the gastric $\mathrm{pH}$ was above 4 was $12 \cdot 2 \%$.

\section{STATISTICAL ANALYSIS}

The percentage time spent in each pH category for each group was expressed as the median \pm interquartile range. For intergroup comparison the data were assumed to be non-parametric and the Wilcoxon's rank-sum comparison was used. To compare the number of patients with normal and abnormal gastric pH profiles the Fisher's exact test was applied. In each case the probability of a $p<0.05$ was regarded as statistically significant.

\section{Results}

The duration of exposure of the lower oesophagus to acid in patients with Barrett's columnar lined lower oesophagus is illustrated in Figure 2, and shows that both groups had markedly increased acid exposure ( $\%$ total time $\mathrm{pH}<4=$ $19 \cdot 2(5 \cdot 1) \% v 19 \cdot 3(4 \cdot 9) \%)$, in comparison with asymptomatic controls. There was, however, no significant difference between the uncomplicated Barrett's patients and those with complications. In contrast, patients with complications of Barrett's columnar lined lower oesophagus had a significantly greater oesophageal alkaline exposure than those without complications (\% total time $\mathrm{pH}>7=24 \cdot 2(6.0) \% v 8.4 \%(3.4)$, Wilcoxon's rank-test $\mathrm{p}<0.05$, Figure 3$)$. Alkaline exposure in uncomplicated patients was similar to that in our control subjects.

Oesophageal motility studies showed that 16 of the 26 patients with Barrett's columnar lined lower oesophagus had a defective lower oesophageal sphincter as defined by Zaninotto et $a l^{19}$ and a similar proportion of each group had weak or ineffective lower oesophageal peristaltic amplitude. The mean peristaltic amplitude in each group is illustrated by the box diagram in Figure 1. In addition $28 \%$ of swallows in the complicated group and $32 \%$ in the uncomplicated group showed non-propagated simultaneous contraction in the distal levels of the oesophageal body.

Sixteen patients underwent simultaneous gastric and oesophageal $\mathrm{pH}$ monitoring. Table II shows that of the seven patients with increased gastric alkaline exposure, five had increased oesophageal alkaline exposure, illustrating a temporal relationship between gastric and oesophageal alkalinisation. In the nine patients with normal gastric $\mathrm{pH}$ patterns eight had a normal oesophageal alkaline profile. This relationship was statistically significant using the Fisher's exact test $(\mathrm{p}<0.05)$.

\section{Discussion}

This study confirms that patients with Barrett's columnar lined lower oesophagus have a marked degree of acid gastrooesophageal reflux, considerably exceeding that seen in the majority of patients with erosive oesophagitis without columnarisation. ${ }^{7}$ The finding of a greater degree of alkaline exposure in the lower oesophagus of patients with complications of their Barrett's 


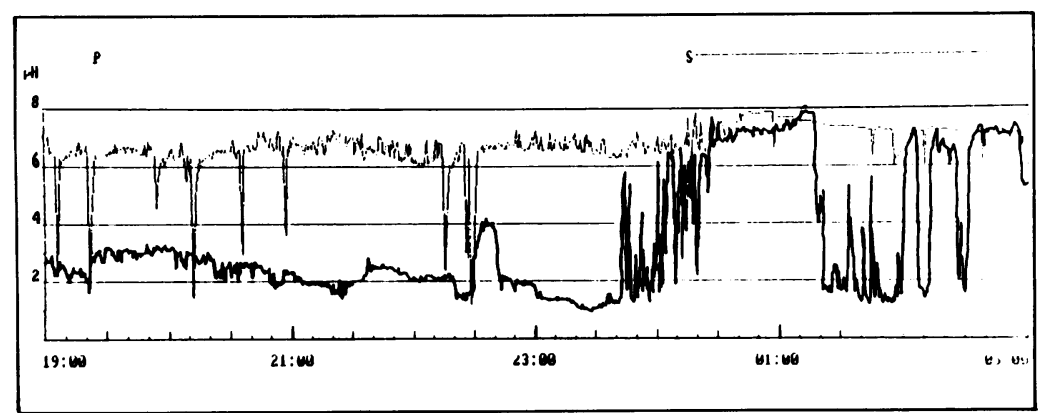

Figure 4: Example of a $\mathrm{pH}$ profile printed by the Gastrosoft computer programme from simultaneous oesophageal and gastric monitoring in a patient with Barrett's oesophagus which illustrates abnormal alkalinity in both the oesophagus (with $p H>7)$ and the stomach $(p H>4)$ Upper tracing is oesophageal and the lower tracing (in heavy print) is the gastric $p H$, which is normal between 2 and 4 initially and then illustrates an alkaline trend which is associated with oesophageal alkalinisation from 00.30 to 01.30 hours.

oesophagus distinguishes them from those without complications and poses the question as to the origin of this distinction.

The data from patients who had undergone simultaneous ambulatory oesophageal and gastric $\mathrm{pH}$ monitoring show a correlation between normal and abnormal gastric and oesophageal alkalinisation. In only three of the 16 patients did the gastric and oesophageal findings disagree. This supports the findings of a previous study which described increased oesophageal alkaline exposure in patients with Barrett's oesophagus. ${ }^{7}$ In order to obviate the criticism of increasing intraoesophageal $\mathrm{pH}$ being related to salivation, however, the present study has extended the application of simultaneous ambulatory oesophageal and gastric $\mathrm{pH}$ monitoring and enabled a valid correlation to be made between oesophageal and gastric alkalinisation. The data from $\mathrm{pH}$ monitoring do not give direct information on the constituents or origin of the body fluids being measured. The relationship between the gastric and oesophageal $\mathrm{pH}$ profiles, however, suggests the probability of duodenogastrooesophageal reflux. Several authors have shown a relationship between the degree of gastric alkalinity and the concentration of bile salts in gastric juice over prolonged periods. Robles et al found a correlation of high gastric $\mathrm{pH}$ and bile concentrations in controls and in patients who had undergone vagotomy and pyloroplasty. ${ }^{20}$ Lendrum et al took samples from the oseophagus of both normal volunteers and patients with Barrett's oesophagus and found a significant correlation between rising $\mathrm{pH}$ and increasing concentrations of bile salts. ${ }^{21}$

Because of the low resting $\mathrm{pH}$ of the stomach, episodes of duodenogastric reflux show relative alkalinity. The per cent time that gastric $\mathrm{pH}$ is $>4$ has been widely used in estimating abnormal

TABLE II Relationship of oesophageal and gastric alkalinisation in patients with Barrett's oesophagus

\begin{tabular}{lll}
\hline & \multicolumn{2}{l}{ Oesophageal alkalinisation } \\
\cline { 2 - 3 } & Normal $^{\star}$ & Increased \\
\hline Gastric alkalinisation & 8 & 1 \\
Normal & & 5 \\
Increased $^{\star}$ & 2 & Bar \\
\hline
\end{tabular}

^Normal values for oesophageal alkalinisation are $<8 \cdot 4 \%$ of the time above $\mathrm{pH} 7$, and for gastric alkalinisation $<12 \cdot 0 \%$ of the time above $\mathrm{pH} 4$. Significant at $\mathrm{p}<0 \cdot 05$, Fisher's exact test. increases in gastric $\mathrm{pH}^{2022}$ Brown et al used this threshold in normal subjects and in patients after cholecystectomy. ${ }^{22}$ It is interesting to note that their normal values were similar to ours, which shows a degree of reproducibility in the normal range. An alternative method of assessing the possibility of duodenogastric reflux is the Fuchs discriminative score. ${ }^{23}$

$\mathrm{pH}>7$ was used to define abnormal alkalinity in the oesophagus because in normal volunteers the $\mathrm{pH}$ of the oesophagus is between 4 and 7 for $96 \%$ of the time. ${ }^{7}$ Time spent outside this range for longer than the 90th percentile in normal subjects implies an abnormal $\mathrm{pH}$ exposure. This does not imply that when the $\mathrm{pH}$ is between 4 and 7 - that is, within the normal range - that there is no reflux. Indeed it is quite possible that at this $\mathrm{pH}$ range there is a mixture of gastric acid and duodenal alkaline juices which may be damaging (with toxic synergism) to the oesophageal mucosa, but this cannot be assessed using the parameter of $\mathrm{pH}$. Qualitative and quantitative assessment of the refluxate during these times of normal $\mathrm{pH}$ awaits developments in new biotechnology.

The association of complications in Barrett's oesophagus with the presence of increased duodenogastric reflux is supported by the presence of increased concentrations of bile salts in gastric aspirates of such patients. ${ }^{12}$ In view of the fact that there is virtually no resistance to gastrooesophageal reflux in patients with Barrett's oesophagus, 124 this increased duodenogastric reflux is likely to result in significant exposure of the oesophageal mucosa to duodenal juices.

Other possible explanations for increased oesophageal alkaline exposure in patients with complicated Barrett's oesophagus include bacterial alkalinisation of saliva either because of pooling in the oesophagus or because of dental infection. The pooling of saliva in this study was minimised by dilatation of the oesophagus before the $\mathrm{pH}$ monitoring period and motility studies showed that a similar proportion of patients in both groups had ineffective peristalsis.

The temporal relationship between oesophageal alkalinisation and abnormal gastric $\mathrm{pH}$ patterns lends support to the belief that the difference in $\mathrm{pH}$ profiles in Barrett's patients is not the result of salivary pooling or excessive salivation. A conclusive argument will only become available, however, when prolonged in vivo measurements of oesophageal bile concentrations or duodenal enzymes can be achieved. Attempts to measure bile salts directly by continuous aspiration have produced conflicting results. ${ }^{25-30}$ Indeed, despite their arguments that bile had little role in the pathogenesis of oesophagitis the data of Gotley $e t a l^{28}$ show that $75 \%$ of patients with gastrooesophageal reflux disease do have bile in their reflux aspirates at concentrations $>30 \mu \mathrm{mol} / 1$ and that higher concentrations of bile were more common at night, at which time our gastric $\mathrm{pH}$ profiles show greatest alkalinity. Further support for this concept has recently come from the work of Iftikhar $e t$ al who showed higher concentrations of bile in oesophageal aspirates from patients with Barrett's columnar lined lower oesophagus. "In considering this, Stoker and Williams conclude that 
when gastric and duodenal secretions mix there may be a toxic synergism between the two that leads to mucosal disruption and intracellular damage to oesophageal cells. ${ }^{29}$

The contribution of duodenogastrooesophageal reflux may be just one of a number of damaging influences in the lower oseophagus of patients with Barrett's oesophagus. From Table I it can be seen that the patients with complications of their Barrett's oesophagus are older (albeit not statistically significant) than patients without complications. It is possible, and indeed would be logical, that increased duration of exposure to gastrooesophageal reflux, independent of the nature of the refluxate, may be a factor in the development of complications in Barrett's oesophagus. This study has clearly shown, however, a correlation between increased alkaline exposure of the stomach and the oesophagus with the development of complications.

These results suggest, first, that simultaneous 24 hour ambulatory oesophageal and gastric $\mathrm{pH}$ monitoring is helpful in patients with Barrett's columnar lined lower oesophagus to help identify those patients at greater risk of developing complications. Patients with increased oesophageal alkalinisation require careful surveillance because of their increased likelihood of developing complications. Second, such findings may have therapeutic implications, as optimal therapy for patients with oesophageal alkaline exposure as well as acid exposure may need to be different from those with acid exposure alone. The role of the individual constituents of duodenal juice in the genesis of complications and of surgical procedures such as antireflux surgery and duodenal diversion in their prevention merits further investigation.

1 Barrett NR. Chronic peptic ulcer of the oesophagus and 'oesophagitis'. Br F Surg 1950; 38: 175-82.

2 Allison PR, Johnstone AS. The oesophagus lined with gastric mucosa membrane. Thorax 1953;8:87-101.

3 Naef AP, Savary M, Ozello L. Columnar lined lower oesophagus : an acquired lesion with malignant predisposition. Report on 140 cases of Barrett's esophagus with 12 adeno-carcinomas. F Thorac Cardiovasc Surg 1975; 70: 82634.

4 Radigan LR, Glover JL, Shipley FE, Shoemaker RE. Barrett's esophagus. Arch Surg 1977; 112: 486-90.

5 Brenmer CG. Barrett's esophagus. In: DeMeester TR Matthews HR, eds. International trends in general thoracic surgery. Vol 3. Benign esophageal disease. St Louis: CV Mosby, 1987: 227-38.
6 Robertson CS, Mayberry JF, Nicholson DA, James PD, Atkinson $M$. Value of endoscopic surveillance in the detecion of neoplastic change in Barrett's oesophagus. Brf Surg 1988; 75: 760-3

7 Attwood SEA, DeMeester TR, Bremner CG, Barlow AP, Hinder RA. Alkaline gastroesophageal reflux: implications in the development of complications in Barrett's columnarlined lower esophagus. Surgery 1989; 106: 764-70.

8 Bremner CG. Barrett's oesophagus. In: Watson A, Celestin LR, eds. Discorders of the oesophagus: advances and controversies. London: Pitman, 1984: 94-104.

9 DuPlessis DJ. Pathogenesis of gastric ulceration. Lancet 1965; i: $974-8$.

10 Lawson HH. Gastritis and gastric ulceration. Br f Surg 1966; 53: 493-6.

11 Van der Veen AH, Dees J, Blankensteijn JD, Blankenstein MV. Adenocarcinoma in Barrett's oesophagus: an overrated risk. Gut 1989; 30: 14-8.

12 Gillen P, Keeling P, Byrne PJ, Healy M, O'Moore RR, Hennessy TPJ. Implication of duodenogastric reflux in the pathogenesis of Barrett's oesophagus. Br $\mathcal{F}$ Surg 1988; 75 . $540-3$.

13 Jenkinson L, Norris TL, Watson A. Expression of the normal ranges in intra-oesophageal pH monitoring. Gut 1987; 28: A1378.

14 Ball C, Norris TL, Watson A. Clinical application of simultaneous ambulatory gastric and oesophageal $\mathrm{pH}$ monitoring. Gut 1987; 28: A1377.

15 Winans CS, Harris LD. Quantitation of the lower esophageal sphincter competence. Gastroenterology 1967; 52: 773-6.

16 Attwood S, Norris T, Jenkinson L, Ball C, Watson A. Standardised method of expression of the normal range of oesophageal body peristalsis. Gut 1988; 29: A1471.

17 Kahrilas PJ, Dodds WJ, Hogan WJ. Effect of peristaltic dysfunction on esophageal volume clearance. Gastroenterology 1988; 94: 73-80.

18 Jenkinson LR, Norris TL, Watson A. Dietary guidelines for ambulatory oesophageal pH monitoring. Gut 1986; 27 : A594.

19 Zaninotto G, DeMeester TR, Schwizer W, Johansson KE Cheng S-C. The lower esophageal sphincter in health and disease. Am f Surg 1988; 155: 104-9.

20 Robles R. Parrilla P Lujan JA, Ponce Marco JL, Sanche Bueno F, Aguayo Albasini JL, et al. 24-hour intragastric $\mathrm{pH}$ measurement in the quantification of duodenogastric reflux measurement in the quant

21 Lendrum K, Evans DF, Robertson CS, Taylor DH, Atkinson $M$. Can oesophageal $\mathrm{pH}$ determine bile reflux in Barrett's oesophagus? Gut 1989; 30: A727.

22 Brown TH, Walton G, Cheadle WG, Larson GM. The alkaline shift in gastric pH after cholecystectomy. Am F Surg 1989, 157: 58-65.

23 Fuchs KH, DeMeester TR, Albertucci M, Schwizer W. Quantification of the duodenogastric reflux in gastroesophageal reflux disease. In: Siewert JR, Holscher AH, eds. Diseases of the esophagus. Berlin: Springer Verlag, 1987: 831-5.

24 Skinner DB, Walther BC, Riddell RH, Schmiodt H, Iascone C, DeMeester TR. Barrett's esophagus: comparison of C, DeMeester TR. Barrett's esophagus: comparison
benign and malignant cases. Ann Surg 1983; 198: 554-66.

25 Gotley DC, Morgan AP, Cooper MJ. Bile acid concentrations in the refluxate in patients with reflux esophagitis. Brf S Surg 1988; 75: 587-90.

26 Johnsson F, Joelsson B, Floren CH, Milsson A. Bile salts in the esophagus of patients with oesophagitis. Scand $\mathcal{F}$ Gastroenterol 1988; 23: 712-6.

27 Mittal RK, Reuben A, Whitney JO, McCallum RW. Do bile acids reflux into the oesophagus? A study in normal subjects and patients with gastroesophageal reflux disease. Gastroenterology 1987; 92: 371-5.

28 Gotley DC, Morgan AP, Ball D, Owen RW, Cooper MI. Composition of gastro-oesophageal refluxate. Gut 1991; 32: 1093-9.

29 Stoker DL, Williams JG. Alkaline reflux oesophagitis. $G u$ 1991; 32: 1090-2.

30 Iftikhar SY, Evans DF, Steele RJC, Ledingham S, Atkinson $M$, Hardcastle JD. Bile reflux in Barrett's oesophagus. $G u$ 1991; 32: A554. 
specialist individual reviews of liver disease and pathophysiology, with an extensive reference list.

This volume's bibliography is limited to the most important or seminal publications. Basic biochemistry, physiology, and pharmacology are not presented separately but are incorporated into pathophysiology. What characterises the book, as well as the way in which the individual contributors have been brought together into a cohesive textbook - and there is much credit to Neil Kaplowitz as editor here is the character of the text, with the use of bold print for bringing out important points, the excellent illustrations, and the use of review or summary tables. This adds up to an altogether admirable volume which must fulfil the purpose of the editor, namely to provide a useful and educationally portable tool.

I have dipped into a number of the chapters, including the initial first section on the structure and function of the liver; the accounts there, as in the clinical sections, are good, represent clear writing with balanced viewpoints, are above all readable and as already emphasised, superbly illustrated. This is a textbook that sets out to educate in hepatology rather than to serve as a vehicle of an individual author's or reviewer's cleverness or expertise in a particular field. It is up to date and can be strongly recommended.

ROGER WILLIAMS

Advances in drug therapy of gastroesophageal reflux disease. Edited by $C$ Scarpignato. ( $\mathrm{Pp}$ 371; not illustrated; £129.60.) Basel: Karger, 1992.

This book is a very mixed package. Some of the chapters are thoughtful, exceptionally well written, giving important insights into gastrooesophageal reflux. These chapters include the introduction entitled 'Aims of Treatment in Gastroesophageal Reflux Disease' and a chapter entitled 'When is Oesophagitis healed?'. Many of the remaining chapters consist of reports of clinical trials. These are encyclopaedic and well referenced but, as might be expected in a book of this type, do not provide light bed time reading.

The most recent advances are possibly the use of cholecystokinin antagonists and motilides and these are introduced to us, being still in the developmental stage. The chapter entitled 'Gastroesophageal Reflux Disease is a Motility Disorder' is rather sketchy. It is generally agreed that inappropriate sphincter relaxation and lower oesophageal sphincter relaxation is the cause of gastro-oesophageal reflux but this is not explored in any depth and neither is the notion of designing drugs to cope with this abnormality.

The book is principally a book of record and reference but also with some useful thoughts to guide further research in gastro-oesophageal reflux.

J F MACKENZIE

If you wish to order or require further information regarding the titles reviewed here, please write to or telephone the BMJ Bookshop, PO Box 295, London WC1H 9JR. Tel: 071383 6244. Fax: 071383 6662. Books are supplied post free in the UK and for BFPO addresses. Overseas customers should add $15 \%$ for postage and packing. Payment can be made by cheque in sterling drawn on a UK bank or by credit card (Mastercard, Visa, or American Express), stating card number, expiry date, and full name. (The price and availability are occasionally subject to revision by the Publishers.)

\section{NOTES}

\section{European Pancreatic Club}

The European Pancreatic Club, XXVth Meeting will be held at Palais des Congrès, Paris, France on 20-23 October 1993. Further information and registration from CPS, 168 Quai Louis Blériot, 75016 Paris (tel: 452434 63; fax: 45257377 ).

American Association for the Study of Liver Diseases

The annual Postgraduate Course - New and Evolving Therapies for Hepatic and Biliary Diseases will be held at the Marriott Hotel in Chicago, Illinois on 4-5 November 1993. The Postgraduate Course will be followed by the 44th Annual Meeting of the American Association for the Study of Liver Diseases on 6-7 November 1993. Further information from: Registration Manager, SLACK Incorporated, 6900 Grove Road, Thorofare, New Jersey 08086-9447. Tel: 6098481000 .

\section{Leeds Course on Clinical Nutrition}

The Leeds Course in Clinical Nutrition will be held on 7-10 September 1993 at St James University Hospital, Leeds. Further information from: Mrs Hilary L Helme, Department of Continuing Professional Education, Continuing Education Building, Springfield Mount, Leeds LS2 9NG. Tel: 0532333233.
Symposium on Gastrointestinal Dysfunction in Neurological Disease

The Symposium on Gastrointestinal Dysfunction in Neurological Disease will be held from 22-23 September 1993 in Omaha, Nebraska. Further information from: Brenda Ram, The Center for Continuing Education, University of Nebraska Medical Center, 600 South 42nd Street, Omaha, Nebraska 68198-5651. Tel: 4025594152 .

\section{Second International Conference of} Gastroenterology, Hong Kong and Chengdu

This conference will take place on 27-29 August 1993 in Hong Kong and on 30 August 2 September 1993 in Chengdu. Further information from: Conference Secretariat, Room 1611-13, World Finance Centre, North Tower, Harbour City, Kowloon, Hong Kong. Tel: 852 736-7837; fax: 852 376-0329.

\section{American Gastroenterological Association}

The American Gastroenterological Association 1993 Fall Postgraduate Course - A Comprehensive Update and Review of Gastroenterology and Hepatology will be held on 9-12 September 1993 at Chicago Marriott Hotel, Chicago, Illinois. Further information from: Registration Manager, SLACK Incorporated, 6900 Grove Road, Thorofare, NJ 080869447. Tel: 609848 1000; fax: 6098485274 .

\section{Eighth International Workshop on Therapeutic Endoscopy}

The Chinese University of Hong Kong and the Hong Kong Society of Digestive Endoscopy Eighth International Workshop on Therapeutic Endoscopy will be held on 30 November - 2 December 1993. Further information from: Dr Sydney Chung, Combined Endoscopy Unit, The Chinese University of Hong Kong, Prince of Wales Hospital, Shatin, NT, Hong Kong. Tel: 852636 2233; fax: 8526350075.

\section{Correction}

Role of intragastric and intraoesophageal alkalinisation in the genesis of complications in Barrett's columnar lined lower oesophagus $G u t$ 1993; 34: 11-5. We regret that an error occurred in the placement of the figure legends in this paper. Figure 1 was labelled with the legend for Fig 3, Fig 2 was labelled with the legend for Fig 1, and Fig 3 was labelled with the legend for Fig 2. 